\title{
PERAN BUDAYA MAULID DALAM MEREKATKAN HUBUNGAN SOSIAL MASYARAKAT BARABAI UTARA (STUDI DESKRIPTIF ANALISIS TERHADAP PENGEMBANGAN NILAI-NILAI BUDAYA PENDIDIKAN IPS)
}

\author{
Oleh: \\ Syarifuddin \\ Dosen, Sekolah Tinggi Ilmu Al-Qur'an Amuntai, Kalimantan Selatan
}

\begin{abstract}
Abstrak
Tujuan penelitian untuk mendeskripsikan dan analisis terhadap nilai-nilai budaya warga Barabai dalam melaksanakan maulid.Penelitian ini menggunakan metode kualitatif dengan jenis penelitian etnografi dalam bentuk antropologi tentang perilaku alami dalam sebuah budaya atau seluruh kelompok sosial. Barabai merupakan pusat pemerintahan Kabupaten Hulu Sungai Utara. Memiliki 12 Desa dan 6 Kelurahan dan memiliki luas $1.472 \mathrm{~km}^{2}$. setiap tahun selalu merayakan maulid hari lahirnya nabi besar Muhammad SAW dengan cara bersama-sama pada setiap desa. Budaya ini sudah ada sejak lama. Dalam pelaksanaannya tersimpan nilai-nilai budaya luhur yang baik untuk diterapkan di dalam kehidupan bermasyarakat. Seperti budaya bermusyawarah/kebersamaan, patuh terhadap pemimpin, gotong royong dan kerja sama. Selain itu juga terdapat nilai-nilai semangat membina kerukunan, silaturahmi antar sesama warga desa, semangat keberagamaan, kerja sama, ketertiban. Peran nilai dalam merekatkan Hubungan Sosial Warga adalah: Nilai sebagai pedoman berperilaku, nilai sebagai kontrol sosial dan nilai sebagai pelindung sosial.
\end{abstract}

Kata kunci: Barabai, Musyawarah, Gotong royong, Nilai 
Syarifuddin: Peran Budaya Maulid dalam Merekatkan Hubungan Sosial Masyarakat Barabai Utara (Studi Deskriptif Analisis Terhadap Pengembangan Nilai-Nilai Budaya Pendidikan IPS)

\section{A. Pendahuluan}

Indonesia merupakan negara yang sangat luas terbentang dari sabang sampai Merauke. Beraneka ragam suku, budaya dan agama. Agama yang paling dominan dinegara Indonesia adalah Islam. ${ }^{1}$ Islam memiliki beraneka ragam budaya, seperti hari besar Islam hari Raya Idul Fitri dan Hari Raya Idul Adha (membuat ketupan, saling berkunjung, ziarah kemakam dll), serta budaya Maulid (memperingati hari lahirnya nabi Muhammad saw).

Budaya dalam pengertiannya diambil dari bahasa sansekerta ${ }^{2}$ ialah buddhayah bentuk jamak dari buddhi yang berarti budi dan akal. Sedangkan menurut $\mathrm{KBBI}^{3}$ adalah Pikiran, akal budi. Sedangkan kebudayaan ${ }^{4}$ adalah hasil kegiatan dan penciptaan batin (akal budi) manusia (seperti kepercayaan, kesenian, dan adat istiadat). E.B Tylor ${ }^{5}$ (1871) mengatakan kebudayaan adalah keseluruhan yang kompleks, yang di dalamnya terkandung ilmu pengetahuan, kepercayaan, kesenian, moral, hukum, adat istiadat, dan kemampuan yang lain serta kebiasaan yang didapat oleh manusia sebagai anggota masyarakat. R. Linton $^{6}$ (1947) berpendapat bahwa kebudayaan adalah konfigurasi tingkah laku yang dipelajari dan hasil tingkah laku, yang unsur pembentukannya didukung dan diteruskan oleh anggota masyarakat tertentu.

Dari pengertian di atas bisa ditarik kesimpulan bahwa kebudayaan adalah suatu perilaku atau tingkah laku yang dilakukan secara turun temurun oleh sekelompok masyarakat, baik itu melalui kepercayaan, kesenian, moral,

1 Bahtiar Effendy, Islam dan Negara-Transformasi Gagasan dan Praktik Politik Islam di Indonesia, Democracy Project, 2011: Islam dan Negara-Transformasi Gagasan dan Praktik Politik Islam di Indonesia (Bukupedia, 2011), 261.

${ }^{2}$ Zeembry, 12 Jurus Pamungkas Animasi kartun Dengan Flash 8 (Jakarta: Elex Media Komputindo, t.t.), 50.

3 Dendy Sugono, Kamus Besar Bahasa Indonesia (Jakarta: Pusat Bahasa, 2008), 226, https://jurnal-oldi.or.id/public/kbbi.pdf.

${ }^{4}$ Sugono, 226.

${ }^{5}$ I. Gede A. B Wiranata, Antropologi Budaya (Citra Aditya Bakti, 2011), 95.

${ }^{6}$ Wiranata, 95. 
Syarifuddin: Peran Budaya Maulid dalam Merekatkan Hubungan Sosial Masyarakat Barabai Utara (Studi Deskriptif Analisis Terhadap Pengembangan Nilai-Nilai Budaya Pendidikan IPS)

hukum, dan adat istiadat.

Dalam ilmu sosial dijelaskan bahwa manusia tidak dapat hidup sendiri dan memerlukan bantuan orang lain. Ada hubungan antara manusia yang satu dengan yang lain. Konsep Social Capital atau dikenal dengan Modal Sosial berpusat pada kebutuhan manusia untuk keterhubungan, makna, kepercayaan dan kontribusi kepada masyarakat yang lebih besar. ${ }^{7}$ Secara umum Modal Sosial merupakan hubungan-hubungan yang tercipta dan norma-norma yang membentuk kualitas dan kuantitas hubungan sosial di dalam masyarakat dalam spektrum yang luas. ${ }^{8}$

Hubungan sosial adalah hubungan timbal balik antara individu yang satu dengan individu yang lain, saling mempengaruhi dan didasarkan pada kesadaran untuk saling menolong. Hubungan sosial juga disebut interaksi Sosial. ${ }^{9}$ Interaksi Sosial adalah proses saling mempengaruhi di antara dua orang atau lebih. Seseorang melakukan hubungan sosial secara naluri di dorong oleh beberapa faktor, baik faktor dari dalam maupun dari luar, faktornya dibedakan menjadi dua yaitu faktor Internal dan Eksternal.

Barabai yang biasa disingkat dengan BRB adalah sebuah kecamatan sekaligus pusat pemerintahan Kabupaten Hulu Sungai Tengah, Provinsi Kalimantan Selatan, Indonesia. Barabai terletak di tepi sungai Barabai dan berjarak sekitar $165 \mathrm{~km}$ di sebelah utara Kota Banjarmasin, ibu kota provinsi (sekitar 4 jam dengan mengendarai mobil). Barabai berada di bawah kaki

7 Ali Alamsyah Kusumadinata, Pengantar Komunikasi Perubahan Sosial (Yogyakarta: Deepublish, 2015), 101.

${ }^{8}$ Alamsyah Kusumadinata, 102.

${ }^{9}$ hari Wijaya, "Peran Budaya Karapan Kerbau Dalam Merekatkan Hubungan Sosial Masyarakat Desa Jotang Beru Kecamatan Empang Kabupaten Sumbawa BesarNtb (Studi Deskriptif Analisis Terhadap Pengembangan Nilai-Nilai Budaya Pendidikan IPS)," Jurnal Penelitian dan Pendidikan IPS 11, no. 2 (2017): 193. 
Syarifuddin: Peran Budaya Maulid dalam Merekatkan Hubungan Sosial Masyarakat Barabai Utara (Studi Deskriptif Analisis Terhadap Pengembangan Nilai-Nilai Budaya Pendidikan IPS)

Pegunungan Maratus yang membujur dari selatan ke utara pulau Kalimantan. ${ }^{10}$

Secara topografi, kabupaten ini terdiri atas tiga kawasan yaitu kawasan rawa, dataran rendah dan wilayah pegunungan Meratus. Semua itu berada pada ketinggian dari 9,53 m dpl (kecamatan Labuan Amas Utara), $25 \mathrm{~m} \mathrm{dpl}$ (kecamatan Barabi), 330 m dpl (kecamatan Batang Alai Timur) dan 1.894 m dpl di gunung Halau-halau (gunung Besar dari Pegunungan Meratus). ${ }^{11}$ Memiliki dua kawasan hutan lindung yakni kawasan hutan lindung Meratus di kecamatan Batang Alai Timur dan kawasan hutan lindung di Gunung Titi di kecamatan Limpasu. Sedangkan aliran sungai kabuoaten ini dialiri oleh dua sungai yaitu sungai Batang Alai dan sungai Barabai. Kota Barabai memiliki dua iklim yaitu musim kemarau dan musim penghujan. ${ }^{12}$

Kota Barabai juga memiliki makanan khas yang cukup terkelanal yaitu Apam Barabai. Selain Apam Barabai, Pakasam juga merupakan makanan khas dari kota ini.

Lapangan Dwi Warna merupakan tempat bersantai untuk anak-anak muda/tua di sore hari. Lapangan ini dikelilingi jalan yang membuatnya menjadi terlihat bersih. Dilapangan ini juga terdapat pepohonan besar dan rindang seperti pohon mahoni dan kenari yang tua namun kuat.

Barabai memiliki sebuah stadion yang bertaraf nasional dengan nam Stadion Murakata, di sana sering diadakan pertandingan antar klub sepak bola. Di samping itu, halaman stadion pun cukup luas, sehingga sering dijadikan

\footnotetext{
10 "Barabai, Hulu Sungai Tengah," dalam Wikipedia bahasa Indonesia, $\begin{array}{llll}\text { ensiklopedia bebas, } & 4 & \text { Juni }\end{array}$ https://id.wikipedia.org/w/index.php?title=Barabai,_Hulu_Sungai_Tengah\&oldid=1513 5793.

11 "Kabupaten Hulu Sungai Tengah," dalam Wikipedia bahasa Indonesia, $\begin{array}{llll}\text { ensiklopedia bebas, } & 25 & \text { Oktober } & \text { 2019, }\end{array}$ https://id.wikipedia.org/w/index.php?title=Kabupaten_Hulu_Sungai_Tengah\&oldid=16 087893.

12 "Kabupaten Hulu Sungai Tengah.”
} 
Syarifuddin: Peran Budaya Maulid dalam Merekatkan Hubungan Sosial Masyarakat Barabai Utara (Studi Deskriptif Analisis Terhadap Pengembangan Nilai-Nilai Budaya Pendidikan IPS)

tempat untuk mengadakan konser-konser artis band ibu kota.

Objek wisata yang dapat dikunjungi di Barabai adalah objek wisata sungai pegunungan Pagat Batu benawa yang terletak $7 \mathrm{~km}$ dari kota Barabai, objek wisata pegunungan Lok Laga yang terletak $15 \mathrm{~km}$ dari kota berada di kecamatan Haruyan, objek wisata air panas yang terletak $10 \mathrm{~km}$ dari kota yang berada di desa Hantakan, objek wisata Gua Limbuhang yang terletak 8,5 km dari kota Barabai berada di desa Haliau, objek wisata Baruh Bunga yang terletak berdempetan dengan Gua Limbuhang tempat wisata ini mengusung tema outbond dan waterpark, tempat wisata Riam Bajandik yang terletak sekitar 0,7 km dari wisata Baruh Bunga dan Gua Limbuhang wisata ini memanfaatkan fasilitas alam yaitu sungai yang dihias sedemikian rupa agar menarik banyak pengunjung. ${ }^{13}$

Barabai juga memiliki pasar di tengah kota seperti Pasar Agrobisnis Modern. ${ }^{14}$ Di Pasar Agrobisnis terdapat berbagai macam kebutuhan seperti sayur, buah, ikan dan daging. ${ }^{15}$ Pada bulan-bulan tertentu penjualan meningkat menjadi 100 kali lipat terutama dibulan maulid.

Maulid atau maulud nabi merupakan peringatan hari lahir nabi Muhammad SAW yang perayaannya diadakan setiap satu tahun kali yaitu jatuh pada tanggal dua belas Rabiul awal dalam penanggalan Hijriyah. Kata maulid

13 brilio.net, "3 Objek Wisata Baru Dan Hits Di Barabai, Kalimantan Selatan," brilio.net, diakses 8 Desember 2019, https://www.brilio.net/creator/3-objek-wisatabaru-dan-hits-di-barabai-kalimantan-selatan-215ce2.html.

14 "Bangunan Pasar Modern Agrobisnis Barabai Rampung, Pedagang Tidak Tahu Jadwal Kepindahan,” Banjarmasin Post, diakses 9 Desember 2019, https://banjarmasin.tribunnews.com/2018/09/03/bangunan-pasar-modern-agrobisnisbarabai-rampung-pedagang-tidak-tahu-jadwal-kepindahan.

15 ANTARA News Agency, "Pasar agrobisnis hanya boleh dijuali tiga komoditi - ANTARA News Kalimantan Selatan," Antara News, diakses 9 Desember 2019, https://kalsel.antaranews.com/berita/73992/pasar-agrobisnis-hanya-boleh-dijualitiga-komoditi.

Al-Madrasah: Jurnal Ilmiah Pendidikan Madrasah Ibtidaiyah Vol. 4, No. 1, Juli-Desember 2019 
Syarifuddin: Peran Budaya Maulid dalam Merekatkan Hubungan Sosial Masyarakat Barabai Utara (Studi Deskriptif Analisis Terhadap Pengembangan Nilai-Nilai Budaya Pendidikan IPS)

atau milad dalam bahasa Arab berarti hari lahir. ${ }^{16}$ Perayaan maulid nabi merupakan tradisi yang berkembang di masyarakat Islam jauh setelah nabi Muhammad SAW wafat yaitu pada masanya para sahabat-sahabat nabi. ${ }^{17}$ Secara umum peringatan ini adalah sebagai bentuk ekspresi atau ungkapan kegembiraan dan penghormatan kepada nabi Muhammad SAW. Pada waktu dulu peringatan maulid nabi diadakan dengan pembacaan doa kepada nabi Muhammad dan juga bersholawat yang di khususkan kepada beliau, para warga muslim berkumpul dan berbondong-bondong pergi ke masjid dan membaca sholawat berzanji bersama-sama.

Peringatan maulid nabi sangat erat dan lekat dengan kehidupan warga Nahdlatul Ulama (NU). Hari senin tanggal dua belas Rabiul awal (Mulud) sudah dihafal diluar kepala oleh warga NU. Acara yang disuguhkan dalam peringatan hari kelahiran Nabi ini begitu beragam, dan kadang diselenggarakan sampai hari-hari dibulan berikutnya, bulan Rabiul tsani (setelah maulud). Ada yang hanya mengirimkan masakan-masakan spesial untuk dikirimkan ke beberapa tetangga kanan dan kiri, ada yang menyelenggarakan upacara sederhana di rumah masing-masing, ada yang lumayan besar seperti yang diselenggarakan di musholla dan masjid-masjid, bahakan ada yang juga menyelenggarakan secara besar-besaran, dihadiri puluhan ribu ummat Islam dan mengundang beberapa kiyai dari berbagai penjuru kota. Ada juga yang merayakannya dengan beberapa tradisi-tradisi yang berbeda sesuai dengan daerah dan lingkungan sekitar dengan simbol yang bermacam-macam pula.

Perayaan maulid Nabi kalau dilihat dari tinjauan sejarah, sudah berlangsung cukup lama sejak ribuan tahun yang silam. Adapun asal-mula diadakan peringatan maulid setidaknya ada 3 versi.

${ }^{16}$ Noor Fajar Asa, Serpihan yang Menerangi (EDU PUBLISHER, 2019), 114.

17 Kholilurrohman, Wewangian Semerbak Dalam Menjelaskan Tentang Peringatan Maulid (Nurul Hikmah Press, 2018), 34.

Al-Madrasah: Jurnal Ilmiah Pendidikan Madrasah Ibtidaiyah

Vol. 4, No. 1, Juli-Desember 2019 
Syarifuddin: Peran Budaya Maulid dalam Merekatkan Hubungan Sosial Masyarakat Barabai Utara (Studi Deskriptif Analisis Terhadap Pengembangan Nilai-Nilai Budaya Pendidikan IPS)

Pertama, perayaan Maulid pertama kali diadakan oleh kalangan dinasti Ubaid (Fathimi) di Mesir yang berhaluan Syiah Ismailiyah (Rafidah). Mereka berkuasa di Mesir tahun 362-567 H, atau sekitar abad 4-6 H. Mula-mula dirayakan di era kepemimpinan Abu Tamim yang bergelar, Al-Mu'iz li Dinillah. Kedua, perayaan maulid dikalangan ahlus sunnah pertama kali diadakan oleh Sultan Abu Said Muzhaffar Kukabari, gubernur Irbil di wilayah Irak. Beliau hidup pada tahun 549-630 H. Ketiga, perayaan maulid pertama kali diadakan oleh Sultan Shalahuddin Al-Ayyubi 567-622 H, penguasa dinasti Ayyub (di bawah kekuasaan daulah abbassiyah). ${ }^{18}$

Di Indonesia sendiri memiliki berbagai macam budaya masyarakat untuk memperingati atau merayakan bulan maulid. Seperti halnya tradisi atau budaya merayakan bulan maulid di daerah Hulu Sungai Tengah. Masyarakat Hulu Sungai Tengah Kota Barabai memiliki tradisi atau budaya tersendiri dalam merayakan bulan maulid atau hari lahirnya nabi Muhammad SAW. Mereka berlomba-lomba untuk berusaha memeriahkan maulid nabi dengan berbagai tradisi-tradisi dan juga kepercayaan masing-masing seiring dengan perkembangan zaman dan pengetahuan. Hal ini yang membuat peneliti tertarik untuk mengetahui lebih dalam lagi mengenai bagaimana tradisi ,maulid nabi yang diadakan untuk penghormatan kepada nabi Muhammad SAW.

\section{B. Metode Penelitian}

Penelitian ini menggunakan metode etnografi dengan bentuk antropologi. Menurut koentjaraningrat ${ }^{19}$ etnografi adalah ilmu sosial yang mempelajari umat manusia pada umumnya dengan mempelajari aneka warna, bentuk fisik, masyarakat serta bentuk kebudayaan yang dihasilkan. Pendekatan

${ }^{18}$ AM Waskito, Pro dan Kontra Maulid Nabi (Pustaka Al Kautsar, 2014), 2324.

${ }^{19}$ Mulyadi, Etnografi Pembangunan Papua (Deepublish, 2019), 2. 
Syarifuddin: Peran Budaya Maulid dalam Merekatkan Hubungan Sosial Masyarakat Barabai Utara (Studi Deskriptif Analisis Terhadap Pengembangan Nilai-Nilai Budaya Pendidikan IPS)

antropologi digunakan untuk mempelajari budaya maulid di Barabai Utara, Kabupaten Hulu Sungai Tengah, Kalimantan Selatan.

Jenis pendekatan dalam penelitian ini menggunakan data kualitatif. Data kualitatif adalah data naratif atau deskriptif yang menjelaskan tentang kualitas suatu fenomena. Dalam mencari data, informan dipilih sesuai dengan judul penelitian yaitu yang mengetahui dan memahami hal-hal yang berkaitan dengan permasalahan penelitian atau purvosive sampling.

Peneliti adalah sebagai instrument utama dalam pelaksana budaya maulid yang meliputi observasi, wawancara dan pengamatan langsung di lapangan dengan menggunakan instrument peneliti yaitu pedoman wawancara yang disusun secara sistematis untuk lebih memfokuskan pada wawancara yang mendalam. Analisis data dalam penelitian kelaitatif dilakukan terus menerus sepanjang proses penelitian berlangsung, yang dilakukan secara deskriptif kualitatif dan interpretatif. Analisis data dilakukan mulai dari perumusan masalah, pengumpulan data dan pasca pengumpulan data. Dengan adanya perumusan masalah maka peneliti telah melakukan analisis terhadap permasalahan tersebut dalam berbagai perspektif teori dan metode yang digunakan.

Oleh karena itu, diperlukan beberapa cara menentukan keabsahan data, sebagai berikut:

a. Triangulasi sumber, pengumpulan data dari beragam sumber yang saling berbeda dengan menggunakan suatu metode yang sama. Seperti wawancara mendalam tentang cara-cara mendapatkan data budaya maulid dari tokoh-tokoh sepuh, perangkat desa dan masyarakat yang terlibat ikut serta dalam memeriahkan maulid nabi. Dalam triangulasi sumber data perlu diperhatikan adanya tiga tipe sumber data yaitu waktu (seperti: kegiatan harian atau musiman), ruang (seperti rumah 
Syarifuddin: Peran Budaya Maulid dalam Merekatkan Hubungan Sosial Masyarakat Barabai Utara (Studi Deskriptif Analisis Terhadap Pengembangan Nilai-Nilai Budaya Pendidikan IPS)

atau dusun/desa), dan orang. Orang sebagai sumber data juga masih dapat dibedakan ke dalam tiga kategori yaitu agregat (individu-individu sampel terpilih), interaktif (grup kecil, keluarga, kelompok kerja), dan kolektivitas (organisasi, komunitas, masyarakat desa).

b. Audit trail, untuk menghindarkan bias atas hasil temuan penelitian, peneliti perlu melakukan cek silang dengan pembimbing di luar penelitian yang dapat memberikan penilaian imbang dalam bentuk pemeriksaan laporan penelitian yang akurat. Hal ini menyangkut deskripsi kelemahan dan kekuatan penelitian serta kajian aspek yang berbeda dari hasil temuan penelitian.

c. Peerdebreefing, mendiskusikan hasil penelitian kepada teman sejawat untuk menghasilkan pemahaman yang lebih luas, komprehensif, dan menyeluruh. Hal ini perlu dilakukan agar peneliti tetap mempertahankan sikap terbuka dan jujur atas temuannya.

d. Member chek, peneliti perlu mengecek temuannya dengan partisipan demi keakuratan temuan, atau member chek adalah proses peneliti mengajukan pertanyaan pada satu atau lebih partisipan untuk tujuan seperti yang telah dijelaskan di atas. Aktivitas ini juga dilakukan untuk mengambil temuan kembali pada partisipan mereka baik lisan maupun tertulis tentang keakuratan laporan penelitian. Pertanyaan dapat meliputi berbagai aspek dalam penelitian tersebut, misalnya apakah deskripsi data telah lengkap, apakah interpretasi bersifat representatif dan dilakukan dan tanpa kecenderungan.

e. Perpanjang pengamatan, bahwa peneliti berada pada latar penelitian pada kurun waktu yang cukup hingga mencapai titik jenuh atas pengumpulan data di lapangan. Waktu akan berpengaruh pada temuan penelitian baik pada kualitas maupun kuantitas. Terdapat beberapa 
Syarifuddin: Peran Budaya Maulid dalam Merekatkan Hubungan Sosial Masyarakat Barabai Utara (Studi Deskriptif Analisis Terhadap Pengembangan Nilai-Nilai Budaya Pendidikan IPS)

alasan dilakukannya teknik ini yaitu untuk membangun kepercayaan informan/subjek dan kepercayaan penelitian sendiri, menghindari distorsi (kesalahan) dan bias, serta mempelajari lebih dalam tentang latar dan subjek penelitian.

\section{Hasil dan Pembahasan}

Perayaan maulid di Barabai Utara komplek perumahan Bulau indah RT 1, Kabupaten Hulu Sungai Tengah, Kalimantan Selatan meliputi: Pelaksanaan, Peraturan, Peralatan dan Peserta. Dapat dijabarkan sebagai berikut:

Pelaksanaan terbagi menjadi 3 yaitu: Sebelum pelaksanaan, saat pelaksanaan dan sesudah pelaksanaan.

a. Sebelum pelaksanaan: Pertama 3 bulan sebelum masuk bulan rabiul awal atau bulan maulid, dikumpulkan warga oleh lurah untuk rapat. pertama menentukan tanggal acara maulid di bulan rabiul awal. Kedua menentukan rumah mana saja yang tahun ini mengikuti acara maulid atau rumah warga mana saja yang ikut memeriahkan acara maulid. Ketiga mengatur pembagian undangan.

b. Saat pelaksanaan: terbagi menjadi 2 undangan umum dan undangan khusus. Pertama undangan umum dimulai dari setelah waktu sholat zuhur atau sekitar jam 02.00 atau pada waktu makan siang hingga berakhir pada jam 18.00. Kedua acaranya adalah menikmati makanan yang telah disediakan oleh tuan rumah (rumah yang mengadakan maulid).

Kedua undangan khusus sekaligus menjadi acara inti dari Maulid. Pertama dimulai setelah waktu isya atau sekitar jam 20.00. Kedua tuan rumah atau perwakilan dari tuan rumah menunggu dilanggar atau tempat yang sudah disediakan panitia, hingga tamu yang diundang datang. Ketiga tamu menuju rumah acara (maulid) bersama-sama 
Syarifuddin: Peran Budaya Maulid dalam Merekatkan Hubungan Sosial Masyarakat Barabai Utara (Studi Deskriptif Analisis Terhadap Pengembangan Nilai-Nilai Budaya Pendidikan IPS)

dengan tuan rumah atau perwakilannya. Keempat tamu dihidangkan jamuan ringan. Kelima dengan adanya kode seperti sholawat, sirine, atau marcon maka acara maulid serentang diadakan.

c. Setelah pelaksanaan: Pertama acara ramah tamah. Kedua sebelum pulang tamu diberi berkat bisa dalam bentuk makanan atau uang.

Peraturan, dalam kegiatan budaya maulid di Barabai Utara terbagi 2, peraturan bagi undangan dan peraturan bagi tuan rumah. Pertama peraturan untuk undangan, ada beberapa peraturan yang harus ditaati seperti: wajibnya memenuhi undangan bagi nama yang sudah terdaftar, kalau tidak hadir ada konsekuensinya yaitu denda uang sebesar Rp. 50.000 (ada desa-desa yang menerapkan hal ini dan ada juga yang tidak menerapkan). Kedua para undangan wajib lapor kepada panitia saat tiba di tempat acara. Ketiga setiap undangan harus berjumlah 1 rombongan dan 1 rombongan terdiri dari 15 orang. Peraturan untuk tuan rumah, Pertama tuan rumah dalam melaksanakan acara inti atau waktu malam hari tidak boleh menggunakan mic atau pengeras suara (mic atau pengeras suara dibolehkan sebelum acara inti yaitu pada saat sore hari atau siang hari) . Kedua tuan rumah harus menunggu aba-aba dari panitia sebelum memulai acara maulid. Ketiga tuan rumah boleh memilih pembacaan Sholawat Berzanji atau Maulid Habsyi atau Maulid Diba'. Keempat tuan rumah boleh menyediakan makanan apa saja.

Peralatan, dalam kegiatan budaya maulid di Barabai Utara alat-alat yang digunakan adalah keperluan untuk jamuan seperti piring, sendok, dan alatalat makan lainnya. Sedangkan untuk acara maulidnya alat yang digunakan adalah terbang $^{\mathbf{2 0}}$ (gendang berbentuk bundar dan pipih yang merupakan khas suku melayu. Bingkai berbentuk lingkaran terbuat dari kayu yang dibubut

20 "Rebana," dalam Wikipedia bahasa Indonesia, ensiklopedia bebas, 10 September 2019, https://id.wikipedia.org/w/index.php?title=Rebana\&oldid=15558989. 
Syarifuddin: Peran Budaya Maulid dalam Merekatkan Hubungan Sosial Masyarakat Barabai Utara (Studi Deskriptif Analisis Terhadap Pengembangan Nilai-Nilai Budaya Pendidikan IPS)

dengan salah satu sisi untuk ditepuk berlapis kulit). Buku Sholawat Barzanji, Buku Maulid Habsyi, dan Buku Maulid Diba'

Peserta, dalam kegiatan budaya maulid di Barabai Utara peserta dalam satu rumah minimal mengundang 1 rombongan, baik rombongan umum dengan ketentuan 1 rombongan adalah 15 orang atau rombongan khusus dengan ketentuan 1 rombongan khusus adalah 30 orang (rombongan khusus adalah grup habsyi).

Bentuk-bentuk kerekatan sosial Masyarakat Barabai Utara komplek Bulau Indah antara lain sebagai berikut: Bermusyawarah/kebersamaan, patuh terhadap pemimpin, gotong royong dan kerjasama.

Mengumpulkan masyarakat dalam suatu tempat yang dilakukan oleh lurah merupakan bentuk dari bermusyawarah untuk merundingkan kegiatan budaya tahunan maulid nabi. Selanjutnya dalam pelaksanaan maulid semua warga komplek RT.01 Bulau indah melaksanakannya dengan serentak dengan menunggu aba-aba dari ketua panitia acara Maulid. Semua warga dalam menyambut acara maulid nabi melakukan bersih-bersih dengan diikuti oleh seluruh warganya secara serentak.

Nilai-nilai yang terkandung dalam kegiatan maulid yang dilaksanakan oleh warga komplek Bulau indah RT.01 adalah mengandung nilai-nilai yang menjadi acuan hidup dalam bermasyarakat. Nilai-nilai itu adalah semangat membina kerukunan, silaturrahim antar sesama warga desa, semangat keberagamaan, kerja sama, ketertiban.

Peran nilai dalam merekatkan Hubungan Sosial Warga Barabai Utara komplek Bulau indah RT 01 adalah: Nilai sebagai pedoman berperilaku, nilai sebagai kontrol sosial dan nilai sebagai pelindung sosial. 
Syarifuddin: Peran Budaya Maulid dalam Merekatkan Hubungan Sosial Masyarakat Barabai Utara (Studi Deskriptif Analisis Terhadap Pengembangan Nilai-Nilai Budaya Pendidikan IPS)

\section{Kesimpulan}

Berdasarkan data-data, hasil dan pembahasan tentang Peran Budaya Maulid Dalam Merekatkan Hubungan Sosial Masyarakat Barabai Utara Komplek Perumahan Bulau Indah RT 1, Kabupaten Hulu Sungai Tengah, Kalimantan Selatan (Studi Deskriptif Analisis Terhadap Pengembangan NilaiNilai Budaya Pendidikan IPS) sebagai berikut:

a. Kegiatan budaya maulid di Barabai Utara komplek Bulau indah terdiri dari: 1) Pelaksanaan: a) Sebelum; b) Saat; dan c) Sesudah, 2) Peraturan: a) untuk undangan dan b) untuk tuan rumah, 3) Peralatan: a) tuan rumah peralatan jamuan dan b) undangan terbang, Buku Sholawat Barzanji atau Buku Maulid Habsyi atau Buku Maulid Diba dan 4) Peserta; satu rombongan terdiri dari 15 orang dan satu rombongan habsyi terdiri dari 30 orang.

b. Bentuk-bentuk kerekatan sosial warga Barabai Utara komplek Bulau indah terdiri dari: Bermusyawarah/kebersamaan, patuh terhadap pemimpin, gotong royong dan kerja sama.

c. Peran nilai dalam merekatkan hubungan sosial warga Barabai Utara komplek Bulau indah adalah 1) nilai sebagai pedoman berperilaku;2) nilai sebagai kontrol sosial; dan 3) nilai sebagai pelindung sosial. 
Syarifuddin: Peran Budaya Maulid dalam Merekatkan Hubungan Sosial Masyarakat Barabai Utara (Studi Deskriptif Analisis Terhadap Pengembangan Nilai-Nilai Budaya Pendidikan IPS)

\section{Daftar Pustaka}

Agency, ANTARA News. "Pasar agrobisnis hanya boleh dijuali tiga komoditi ANTARA News Kalimantan Selatan." Antara News. Diakses 9 Desember 2019. https://kalsel.antaranews.com/berita/73992/pasaragrobisnis-hanya-boleh-dijuali-tiga-komoditi.

Alamsyah Kusumadinata, Ali. Pengantar Komunikasi Perubahan Sosial. Yogyakarta: Deepublish, 2015.

Banjarmasin Post. "Bangunan Pasar Modern Agrobisnis Barabai Rampung, Pedagang Tidak Tahu Jadwal Kepindahan.” Diakses 9 Desember 2019. https://banjarmasin.tribunnews.com/2018/09/03/bangunan-pasarmodern-agrobisnis-barabai-rampung-pedagang-tidak-tahu-jadwalkepindahan.

"Barabai, Hulu Sungai Tengah.” Dalam Wikipedia bahasa Indonesia, $\begin{array}{lllll}\text { ensiklopedia bebas, } & 4 & \text { Juni }\end{array}$ https://id.wikipedia.org/w/index.php?title=Barabai,_Hulu_Sungai_Teng ah\&oldid=15135793.

brilio.net. "3 Objek Wisata Baru Dan Hits Di Barabai, Kalimantan Selatan." brilio.net. Diakses 8 Desember 2019. https://www.brilio.net/creator/3objek-wisata-baru-dan-hits-di-barabai-kalimantan-selatan-215ce2.html.

Effendy, Bahtiar. Islam dan Negara-Transformasi Gagasan dan Praktik Politik Islam di Indonesia, Democracy Project, 2011: Islam dan NegaraTransformasi Gagasan dan Praktik Politik Islam di Indonesia. Bukupedia, 2011.

Fajar Asa, Noor. Serpihan yang Menerangi. EDU PUBLISHER, 2019. 
Syarifuddin: Peran Budaya Maulid dalam Merekatkan Hubungan Sosial Masyarakat Barabai Utara (Studi Deskriptif Analisis Terhadap Pengembangan Nilai-Nilai Budaya Pendidikan IPS)

"Kabupaten Hulu Sungai Tengah." Dalam Wikipedia bahasa Indonesia, ensiklopedia bebas, $25 \quad$ Oktober 2019. https://id.wikipedia.org/w/index.php?title=Kabupaten_Hulu_Sungai_Te ngah\&oldid=16087893.

Kholilurrohman. Wewangian Semerbak Dalam Menjelaskan Tentang Peringatan Maulid. Nurul Hikmah Press, 2018.

Mulyadi. Etnografi Pembangunan Papua. Deepublish, 2019.

"Rebana." Dalam Wikipedia bahasa Indonesia, ensiklopedia bebas, 10 September 2019. https://id.wikipedia.org/w/index.php?title=Rebana\&oldid=15558989.

Sugono, Dendy. Kamus Besar Bahasa Indonesia. Jakarta: Pusat Bahasa, 2008. https://jurnal-oldi.or.id/public/kbbi.pdf.

Waskito, AM. Pro dan Kontra Maulid Nabi. Pustaka Al Kautsar, 2014.

Wijaya, Hari. "Peran Budaya Karapan Kerbau Dalam Merekatkan Hubungan Sosial Masyarakat Desa Jotang Beru Kecamatan Empang Kabupaten Sumbawa Besar-Ntb (Studi Deskriptif Analisis Terhadap Pengembangan Nilai-Nilai Budaya Pendidikan IPS)." Jurnal Penelitian dan Pendidikan IPS 11, no. 2 (2017): 188-99.

Wiranata, I. Gede A. B. Antropologi Budaya. Citra Aditya Bakti, 2011.

Zeembry. 12 Jurus Pamungkas Animasi kartun Dengan Flash 8. Jakarta: Elex Media Komputindo, t.t. 
Syarifuddin: Peran Budaya Maulid dalam Merekatkan Hubungan Sosial Masyarakat Barabai Utara (Studi Deskriptif Analisis Terhadap Pengembangan Nilai-Nilai Budaya Pendidikan IPS)

Al-Madrasah: Jurnal Ilmiah Pendidikan Madrasah Ibtidaiyah

Vol. 4, No. 1, Juli-Desember 2019 